\title{
Frugal Innovation Hijacked: The Co-optive Power of Co-creation
}

\author{
Linda Annala Tesfaye ${ }^{1} \cdot$ Martin Fougère ${ }^{1}$ (I)
}

Received: 11 July 2020 / Accepted: 24 June 2021 / Published online: 5 July 2021

(c) The Author(s) 2021

\begin{abstract}
In this paper we investigate how different discourses on frugal innovation are articulated, and how the dynamics between these different discourses have led to a certain dominant understanding of frugal innovation today. We analyse the dynamic interactions between three discourses on frugal innovation: (1) innovations for the poor, (2) grassroots innovations by the poor, and more recently (3) co-creating frugal innovations with the poor. We argue that this latter discourse is articulated as a hegemonic project as it is designed to accommodate demands from both business and poor communities. We draw on Laclau and Mouffe's concepts of 'chain of difference', 'empty signifier' and 'floating signifier' to explain the advent of the hegemonic discourse on co-creating innovations with the poor. We show how a floating signifier with radical potential, frugal innovation, has been hijacked and co-opted in a hegemonic project that has leveraged powerful ambiguous signifiers, with co-creation acting as an empty signifier. To clarify what is problematic in this hegemonic intervention, we expose how contemporary frugal innovation discourse contributes to a project of governing and exploiting rather than helping the poor, in ways that benefit formal economic actors while further worsening global inequalities.
\end{abstract}

Keywords Chain of difference $\cdot$ Co-creation $\cdot$ Empty signifier $\cdot$ Floating signifier $\cdot$ Frugal innovation $\cdot$ Sustainable innovation

\section{Introduction}

'Innovation' continues to be a catch-word with positive associations, a signifier that is deployed in business and policy to imply good impacts on the economy and society (Godin, 2016; Gripenberg et al., 2012; Perren \& Sapsed, 2013). Having become a defining feature of (Western) hegemonic modernity during the twentieth century (see Godin, 2016), the term today stands for that which provides the solutions for market needs and wants, as well as for a variety of societal ills and problems-thus, its absolute positivity is taken for granted (see e.g., Gripenberg et al., 2012; Liu \& Pechenkina, 2019). While it was not a particularly dominant concept in the Brundtland report (WCED, 1987), 'innovation' has now become highly prevalent within contemporary sustainable development discourse-apparently

Martin Fougère

martin.fougere@hanken.fi

Linda Annala Tesfaye

linda.annala@hanken.fi

1 Hanken School of Economics, Arkadiankatu 22, P.O.

Box 479, 00101 Helsinki, Finland
20 times as prevalent, from being mentioned only 13 times in the Brundtland report's approximately 400 pages, to 26 times in the 40-page Agenda 2030 document (UN Sustainable Development, 2015). The UN Sustainable Development Goals (SDGs) have explicitly made innovations the key for tackling sustainability challenges of numerous sorts: "without innovation there is no way to overcome the challenges of our time" (UN Secretary-General, 2017).

Various types of innovation concepts have recently proliferated in the arena of sustainable development: inclusive, reverse, grassroots, green, social innovations-just to name a few-have created diverse sets of meanings under the umbrella of sustainable innovation. This paper looks into the recent emergence of a new member in the family of sustainable innovations: frugal innovation. In its literal sense, the word frugal means "simple", "plain", or "using money or supplies in a very careful way" (Merriam Webster, 2019). Frugal innovations are typically framed as innovations driven by scarce resources and regional circumstances of poverty and exigency (Pansera \& Martinez, 2017). Commonly credited for enhancing efficiency of resource utilization (Zeschky et al., 2014), frugal innovations generally refer to products, technologies and services 
developed in and for resource-constrained environments. A typical example would be the Mitticool, a clay refrigerator that does not require electricity and costs less than 50 USD (Wierenga, 2015). Mitticool was developed by a clay craftsman in a Gujarati village and it continues to be an economic success story of frugal innovations.

The idea of frugal innovation is not new: developing "good-enough", simple products for 'the poor' can be traced back to the appropriate technology movement in the 1970s, initiated by Ernst Schumacher (Kaplinsky, 2011; Schumacher, 1973). Frugal innovations have gained heightened attention in their countries of origin (The Economist, 2014), and their growing global reputation has attracted powerful actors from the global North to get involved in the business as well (Hossain, 2016; Pansera \& Owen, 2017). Transnational corporations such as Philips, Bosch, General Motors and $3 \mathrm{M}$ have allegedly adopted frugal innovation practices in their subsidiaries and established collaborative research centers in India, Kenya, China and South Africa.

Why are innovations - and more specifically frugal innovations-increasingly incorporated in sustainable development discourse? Whose interests are being served while promoting frugal innovations as win-win solutions to sustainable development challenges? Despite the increasing popularity of frugal innovations, the academic literature on them remains scant and calls for more empirical and theoretical studies to answer such questions (Bhatti, 2012; Hossain, 2018; Knorringa et al., 2016; Tiwari et al., 2016). In this paper we investigate how different discourses on frugal innovation relate to the 'sustainable innovation' field of discursivity, and how the dynamics between these different discourses have led to a certain dominant understanding and implications of frugal innovation today. Through a genealogical problematizing review (Alvesson \& Sandberg, 2020; Quistgaard Steensen \& Villadsen, 2020), we find that discourses on frugal innovation can be traced back to discourses on (1) innovations for the poor, and (2) grassroots innovations by the poor. In illustrating the community-driven discourse on grassroots innovations by the poor, we particularly draw on the context of India. We also find that more recently, a third discourse drawing connections with these two discourses has advanced a more governance-driven perspective on co-creating frugal innovations with the poor. We argue that this latter discourse is articulated as a 'hegemonic project' (Torfing, 1999) as it is designed to accommodate demands from both business and poor communities, and deployed in order to govern the poor through the increasingly usual discursive mix of 'empowerment' and 'responsibilization' (see e.g., Ilcan \& Lacey, 2011), complemented by an exploitation of the resulting activation of frugal creativity, as enabled by 'co-creation' (Cova et al., 2011; Zwick et al., 2008).
For our analysis, we draw on Laclau and Mouffe's (1985, p. 130) concept of 'chains of difference' to illustrate the hegemonic formation of the governance-driven discourse of co-creating innovations with the poor. A chain of difference smoothens the differences between the elements of a discourse, preventing or preempting the expression of antagonism through for example practices of cooptation (Howarth, 2006), and thereby making it possible for differences to be tolerated or even celebrated while largely preserving or reinforcing the hegemonic order. We separate the discourses and their historical developments in a sequence for presentational purpose, although we do acknowledge their parallel and interactive character. By focusing on the unfolding of the meanings surrounding frugal innovation, we want to explore and trace the three discourses, which are reinforcing, contesting and shaping meanings associated with the concept of frugal innovation. In framing our study through discourse theoretical concepts such as 'chain of difference', 'empty signifier' and 'floating signifier', we contribute to the analysis of the foundational ideas and notions underpinning frugal innovation, and we expose how contemporary frugal innovation discourse serves a purpose in a hegemonic project of governing the poor in ways conducive to 'wealth creation' and 'economic development' as per mainstream, elite-driven definitions. We engage with 'theories' of frugal innovation and co-creation not to 'improve' or 'contribute to' them but instead to problematize their impacts and power effects. We believe there is an inherent value in problematizing and unpacking how 'theories' attached to hegemonic projects have undesirable effects when deployed as powerful discourses, and thus we do not pursue a 'theoretical contribution' to these theories. Our approach here is 'ethicopolitical' (see e.g., Bell \& Willmott, 2020), and we could describe its inherently critical stance towards contemporary neoliberal hegemony as follows: we take issue with the 'one policy fits all' neoliberal solution of making as many people as possible 'innovators' and 'entrepreneurs' while prioritizing capital accumulation for already powerful investors and assuming that all will go well, despite the abundance of evidence over the past 50 years that such neoliberal policies lead to rising socio-economic inequalities. We show how a floating signifier with radical potential, frugal innovation, has been hijacked and co-opted in a hegemonic project that has leveraged a powerful empty signifier (co-creation) and other key signifiers (Bottom/Base of the Pyramid, partnerships, scaling up), all associated with marketing and business ethics. And to make it clear what is problematic in this hegemonic intervention, we discuss a number of critical implications of the advent of the co-creation discourse on frugal innovation.

In the next section, we introduce Laclau and Mouffe's (1985) post-Marxist discourse theory, focusing in particular on the concept of 'chain of difference'. We then move on to 
our analysis of discourses on frugal innovation in relation to the sustainable innovation field of discursivity, in four parts. Our discussion is then devoted to critical implications of the current hegemonic discourse on frugal innovation.

\section{A Discourse Theoretical Approach: Methodological and Conceptual Considerations}

The process of studying discourses on frugal innovation started with an aim to understand the complexities surrounding the use of the term in scholarly articles, as well as in the talks of practitioners. Managerial and academic representations on frugal innovations - as we perceived 2 years agowere typically filled with positivity and numerous success stories, while critical perspectives on the phenomena were left out of the discussions. It was this hegemonic ambiguousness on frugal innovations that led us to explore the literature in more detail. We started by exploring the historical emergence of frugal innovation as an established concept, and continued to analyze its relationship with the broader field of discursivity of sustainable innovations. The historical study of discourses allows for the creation of distance to texts and empirical phenomena through a strategy of moving away from the centre through time. Such strategy is common in studies drawing on Laclau and Mouffe's post-foundational discourse theory (Jørgensen \& Phillips, 2002) with ambitions of drawing ethico-political implications. As Bell and Willmott (2020) suggest, rather than appealing to established technical methodological norms, dealing with ethicopolitical critique entails relying on 'intellectual craftship' (Mills, 1959) in designing an idiosyncratic methodological approach. Although Laclau and Mouffe worked little on detailed analysis of empirical materials, their concepts can be useful tools for studying empirical phenomena (Howarth, 2005; Jørgensen \& Phillips, 2002). Our methodology here involved four stages which were not pre-set from the beginning since the results of the first stage warranted the next three: (1) through a genealogical problematizing literature review (Alvesson \& Sandberg, 2020; Quistgaard Steensen \& Villadsen, 2020), studying the historical development of the concept of frugal innovation, different discourses dealing with it, and identifying the contemporary hegemonic discourse on it; (2) analysing the differential vs. equivalential dynamics in the developments of the different discourses, in line with Laclau and Mouffe's (1985) distinction between logic of difference and logic of equivalence; (3) denaturalizing the contemporary hegemonic discourse (Fournier \& Grey, 2000) by more closely studying its articulation through a chain of difference and a number of powerful ambiguous signifiers; and (4) critically reflecting on the power effects (Knights \& Morgan, 1991) of the contemporary hegemonic discourse. The stages are reflected in the structure of the article as follows: stage 1 in the lengthy descriptions of each of the three main discourses; stage 2 in the relatively brief analytical comments in relation to the first two discourses, and the more extensive analysis of the third, hegemonic discourse, where it is largely combined with stage 3 ; and stage 4 in the discussion and conclusions section.

In the first stage of our methodology, as mentioned above, we studied the historical origins of the frugal innovation concept. This process was inspired by Foucault's genealogical approach with an aim to describe the 'conditions of historical appearance' (Foucault, 2002, p. 48). We conducted a problematizing literature review (Alvesson \& Sandberg, 2020) which encompassed a broad reading on the topic of frugal innovations (both academic and practitioner texts) and a more focused study of key references (see Table 1). The problematizing literature review is primarily guided by the principles of 'reading more broadly but selectively', 'problematizing and not accumulating', and 'less is more' (Alvesson \& Sandberg, 2020, p. 1297). In the process of trying to understand the concept of frugal innovation and the conditions of its origin, we found out that (1) frugal innovation is mostly related with 'the poor', and (2) the key difference between discourses lies in the role assigned to 'the poor' in conceptualizing frugal innovation. In the early discourses on frugal innovation, there were two such roles: frugal innovation for the poor, and frugal innovation by the poor. The third role of frugal innovation with 'the poor' emerged later. During the more in-depth tracing of these categories within the key reference texts (see Table 1), the "for" became associated with business-driven articulations of sustainable innovations (as particularly promoted in e.g. Prahalad, 2006; Prahalad \& Hart, 2002), the "by" chiefly

Table 1 Discourses on frugal innovations

\begin{tabular}{lll}
\hline Discourse on frugal innovation & Approach to sustainable innovation & Key references \\
\hline $\begin{array}{l}\text { Frugal innovation for the poor } \\
\text { Frugal innovation } b y \text { the poor }\end{array}$ & $\begin{array}{c}\text { Business-driven articulations } \\
\text { Community-driven grassroots articulations }\end{array}$ & $\begin{array}{c}\text { Prahalad (2006), Prahalad and Hart (2002) } \\
\text { Gupta (2006), Smith et al. (2014), Pansera } \\
\text { and Sarkar (2016) }\end{array}$ \\
Frugal innovation with the poor & Karnani (2007), Simanis and Hart (2009), \\
& & Radjou and Prabhu (2014)
\end{tabular}


related to community-driven grassroots innovation articulations (as studied in e.g. Gupta, 2006; Pansera \& Sarkar, 2016; Smith et al., 2014), and the latest "with" was something that we termed governance-driven articulations (as discussed in e.g.; Karnani, 2007; Radjou \& Prabhu, 2014; Simanis \& Hart, 2009).

Thus, we focused on key texts which we found to represent each of the three discourses. While reading the texts for the third, governance-driven discourse, it became clear that an important signifier was the notion of co-creation. We found that this signifier seems to tie together the categories of "for" and "by", thus creating a powerful empty signifier which is difficult to criticize or circumvent.

In the second and third stages of our methodology, we gradually move from a descriptive approach to a more analytical one. In those stages, we work more explicitly with Laclau and Mouffe's (1985) discourse theoretical concepts such as the logics of equivalence and difference (second stage) and empty and other ambiguous signifiers (third stage) in order to analyze the dynamics in the developments of the different discourses on the business-driven (previously philanthropy-driven) innovation for the poor; the community-driven innovation by the poor; and the governance-driven innovation with the poor. Within management and organization studies, a number of scholars have been inspired by Laclau and Mouffe's (1985) post-foundational discourse theory to investigate organizational phenomena with the conceptual tools provided by this theoretical approach (e.g., Islam et al., 2017; Kelly, 2013; Kenny \& Bushnell, 2020; Kenny \& Scriver, 2012; Nyberg \& Wright, 2012; O'Doherty, 2015; Smolović Jones et al., 2020; Spicer \& Böhm, 2007; Spicer \& Sewell, 2010; Zueva \& Fairbrass, 2019). By discourse, Laclau and Mouffe (1985, p. 105) refer to a "structured totality resulting from [an] articulatory practice", that is, "any practice establishing a relation among elements such that their identity is modified". In other words, an articulatory practice may lead to a change of meanings by modifying the identity of elements, yet it does not become a discourse until it is also characterized by a degree of "fixation' in meaning (Jørgensen \& Phillips, 2002). When articulatory practice modifies the meanings of elements, some of the meanings of those elements become fixed, transforming these elements into what Laclau and Mouffe (1985) call 'moments'. However, the degree of fixation of meaning is never absolute; instead, meanings are contingent upon possible different (re)articulations of discourses.

In this study, 'frugal innovation' is studied as a floating signifier; that is, different discourses engaging with the signifier 'frugal innovation' fill it with different meanings. 'Cocreation' is understood in this study as an empty signifier (Laclau, 1996), "meaning that it acts as a kind of anchoring and connective word that threads together the moments [and other ambiguous signifiers] that assemble [the now hegemonic] discourse" (Smolović Jones et al., 2020, p. 539) on frugal innovation, that of frugal innovation with the poor. What we mean by 'key signifiers' in this study refers to the other ambiguous signifiers that are other nodes in the discourse, such as 'Base of the Pyramid' and 'partnership'; they are not 'moments' since their ambiguity remains and contributes to the chain of difference.

Two other central notions of Laclau and Mouffe's (1985) discourse theory are the logic of equivalence and the logic of difference, the inspiration of which come from linguistics but which are applied to hegemonic or counter-hegemonic projects in the social realm. Contu et al., (2013, pp. 369-370) explain that "in the social domain, the elements [subjected to these logics] are social groups, their words and actions" and that "in the logic of equivalence, one element ' $a$ ', while still holding its particularity, comes to incarnate something that metaphorically brings together (i.e. makes equivalent) all the other elements ' $b$ ', 'c', and 'd' constituting a chain of equivalence that articulates a collective will". Thus, they note that this connective element (an empty signifier) is akin to what in linguistics is called synecdoche, as in one element standing for the whole. For such different elements to become 'equivalent', there needs to be an outside that threatens all the elements and against which all the elements are framed. Thus, 'chains of equivalence' typically form against a constitutive outside (see Laclau, 1996), and they particularly characterize counter-hegemonic movements framed against an established order. For example, successful populist movements tend to rely on chains of equivalence by being united against the elites or the establishment (Laclau, 2005; see also de Cleen et al., 2018).

In contrast, the logic of difference refers to a process where different elements $a, b$, and c remain differentially positioned but somehow are structured in a chain, as part of the same system anyway (Contu et al., 2013). Thus, chains of difference deliver a smoothing effect, as the differences between the elements, rather than expressed through antagonism, get to be tolerated or even celebrated. At the heart of such chains, there typically is a "logic of pre-emption in which the possibilities of conflict are forestalled before they are able to become antagonistic constructs [for example through] practices of cooptation..." (Howarth, 2006, p. 114; emphases in the original). Thus, such chains may develop dynamically as a result of a challenge to the hegemonic block or simply an attempt to consolidate a hegemonic order through a hegemonic project extending the reach of the hegemonic block. In these cases, a chain of difference might develop as a result of a discourse that to some extent succeeds at re-legimizing the hegemonic order, for example through arguing for a differentiated win-win-win for differentiated groups in society (see e.g., Fougère et al., 2017).

Both types of chains need powerful empty signifiers in order to be established and sustained. While a chain of 
equivalence needs an empty signifier often based on synecdoche and while the equivalence comes from a common difference to an outside, a chain of difference needs different kinds of signifiers, signifiers that draw connections between different identities - and between different demands-not by making them equivalent in their common difference to an outside but by affirming their difference to one another. Thus, while the signifiers establishing and sustaining chains of difference might be just as ambiguous as empty signifiers associated with chains of equivalence, their main function is not to create equivalence but to connect differences with one another. While to date there has been a paucity of research on exactly how empty signifiers work in establishing chains of difference, one intuition from Contu et al. (2013) is that the kind of empty signifier needed might be akin to a tertium quid, that is, an "unknown or indefinite thing related in some way to two [or more] known or definite things, but distinct from both[/all]" (Collins, 2021).

Both chains of equivalence and chains of difference are closely connected to the notion that every discourse competes for hegemony within a field of discursivity, attempting to dominate this field (Torfing, 1999). While discourses that are already dominant often rely on a chain of difference, where societal differences are institutionalized in a hegemonic order, counter-hegemonic discourses typically rely on as broad as possible chains of equivalence in order to stand a chance in challenging the hegemonic block (see e.g., Fougère \& Solitander, 2020; Kenny \& Bushnell, 2020). In order to hegemonize the field of discursivity a discourse needs to establish a chain (of difference or equivalence) that fixes the meaning of key 'floating signifiers' (Laclau \& Mouffe, 1985), i.e. those signifiers whose meanings differ from one discourse to another. In this paper, 'frugal innovation' can be understood as a floating signifier whose meaning varies across discourses-such as in business-driven discourses on sustainable innovation vs. community-driven discourses on sustainable innovation. Hegemony can be argued to be established if a single discourse succeeds in standing in for the whole field of discursivity. In this context, the discourses on 'innovations for the poor' and 'grassroots innovations by the poor' become undermined from the discursive field of sustainable innovations, from which the 'co-creation with the poor' overpowers or dissolves them by rearticulating their elements through a chain of difference (Jørgensen \& Phillips, 2002). While a hegemonic discourse can be strongly naturalized as the one established way to understand a particular aspect of reality, it is never absolute, otherwise it would mean that we would not be able to see its contingency as 'hegemony', but rather as fully 'objective' discourse (e.g., Jørgensen \& Phillips, 2002). For example, sustainable development discourse as institutionalized through the SDGs has a vocation to be hegemonic. While it is difficult to resist its injunction to frame all sustainability endeavours in terms of SDGs, it is nevertheless not impossible to see SDGs as contingent articulations, which may be contested. Indeed, a feature of hegemony is that because of its contingent nature, it does not exist without resistance (e.g., Burawoy, 1979; Laclau \& Mouffe, 1985). Given that hegemony for Laclau and Mouffe (1985) is inherently unstable, once provisionally established it necessitates discursive work to maintain and reproduce it (Spicer \& Sewell, 2010).

In our study of discourses on frugal innovation, we set out to look into what discourse today is closest to what could be called a hegemonic discourse on sustainable innovation, and what meaning frugal innovation is assigned within such discourse.

\section{Discourses on Frugal Innovation and the Sustainable Innovation Field of Discursivity}

Our discourse analysis focuses in turn on: (1) 'sustainable innovation' as an evolving field of discursivity; (2) different relevant historical articulations of sustainable innovations for the poor; (3) relevant articulations of sustainable innovations by the poor; and (4) more recent articulations of sustainable innovations with the poor, which seem to be successful at creating a chain of difference through frugal innovation, indebted to the 'co-creation' empty signifier and other key signifiers.

\section{Sustainable Innovation as an Evolving Field of Discursivity}

Before proceeding to analyzing frugal innovation in more detail, it is useful to relate its emergence to the broader narrative of sustainable innovation. The amalgamation of sustainability and innovation-two fundamental aspects of contemporary economic thinking and global governancetowards the different discourses on 'innovation for sustainable development' progressed against a background of dual separate developments. In the late 1980s, two parallel processes that would get to exert strong influence on policy and practice worldwide were initiated: The Brundtland report 'Our Common Future' on sustainable development; and the far less known two Nordic workshops (the first on the basis of a paper from the Nordic Science Council in 1988; the second in Oslo in 1989) that resulted in the first Oslo manual on measuring innovation activities. While the Brundtland report defined the new, hegemonic way of thinking about development and growth through the discourse of sustainable development (Brown, 2016), the Oslo manual can also be argued to have provided a hegemonic way of thinking about innovation (see Fougère \& Harding, 2012) through 
collecting and interpreting innovation data from companies in different OECD countries.

The recent formulation of the UN Sustainable Development Goals (SDGs) signaled the broadening of the discursive field for corporations to legitimize their role in innovating for sustainable development (Voegtlin \& Scherer, 2017). The role of corporations within the SDGs is part of a larger and contested narrative: private corporations, as important contributors of innovation, should gain a legitimate position in addressing problems of public concern relating to sustainability, based on their essential resources and room for action (Schrempf, 2014; Voegtlin \& Scherer, 2017; Young, 2011). The win-win proposition of sustainable innovation lies in its ability to hold out a promise of solving sustainability challenges, while simultaneously contributing to economic growth. An opposing view to corporations' increased influence within sustainable development discourse emphasizes the necessity of addressing sustainability on a more collective level. Such processes ought to proceed through democratic governance mechanisms, and limit the involvement of corporations in such issues of public concern (e.g. Edward \& Willmott, 2008; Mäkinen \& Kourula, 2012). This same controversial discussion on the position of corporations in the realm of sustainable innovations is present within frugal innovations: while the discourses on sustainable innovation for the poor obviously call for external actors (and today, mainly multinational corporations) to take a leading role in producing frugal innovations for the market needs, the community-driven discourse on innovation by the poor typically places the local needs as their starting point. In the following, we will have a closer look at the differences between these discourses, and proceeding to a description of the third discourse, on sustainable innovation with the poor, which we argue represents a hegemonic project.

\section{Different Articulations of Sustainable Innovation for the Poor}

Historically, two important articulations have advanced thinking on sustainable innovation for the poor: first, the Appropriate Technology discourse, which in some way merged into the Sustainable Development agenda in the 1980s, and second, as part of the business response to the latter agenda after the 1990s, the Base of the Pyramid (BoP) discourse.

\section{Sustainable Innovations at the 'Local' Level: the Legacy of the Appropriate Technology Movement}

Going back to the historical roots of frugal innovations, many of the key notions in framing the idea of 'innovation for the poor' can be found in the Appropriate Technology movement of the 1950s. Bhatti and Ventresca (2012) even suggest frugal innovation to be a direct continuation of this specific movement. Appropriate technology is characterized as one of the most influential discourses on technology in the global development sector (Bell \& Franceys, 1995). It started with a not-for-profit agenda, largely influenced by development economist E. F. Schumacher and his persuasive book 'Small Is Beautiful: A Study of Economics As If People Mattered' (1973). The movement arose from a recognition that most global technological solutions were directed to satisfy the needs of the global rich, therefore designed to operate in high-income environments (Kaplinsky \& Farooki, 2010). Thus, from the beginning the question of desirable technology for different people around the world was framed in terms of differentiated needs, that is, in a differential logic. It grew during the time of the energy crisis in the 1970s and the burgeoning environmental movement, therefore encapsulating a strong emphasis on environmental sustainability (NCAT, 2011). The definition of appropriate technology was disputed since its emergence, but certain common denominators exist within the literature: appropriate technology encompasses technologies that are environmentally sustainable, energy-efficient, small-scale, decentralized, labor-intensive and locally autonomous (Hazeltine \& Bull, 1999). Such technologies create workplaces located where people live, they are affordable for everyone to use, and they utilize local materials and simple techniques to create material objects for local consumption (Schumacher, 1973). They incorporate "appropriate" characteristics for a specific time and place, thus rejecting the idea of universalistic, linear models of technology. The ideological aim of the appropriate technology movement was to demand for an alternative to the traditional technology transfer of capitalintensive products from industrialized nations to the global South (Akubue, 2000) towards the transfer of more appropriate technologies for the poor. In this sense, the logic of difference characterizing the Appropriate Technology movement was philanthropy-driven rather than business-driven, as the idea was to provide those technologies that the poor most needed, regardless of business opportunities.

After a quick rise, the Appropriate Technology movement experienced a steady decline from the late 1970s on. During the 1980s, many of the institutions built around promoting appropriate technologies either disappeared or lost their significance. Some of the technologies that had gained momentum as part of the movement, such as solar energy, windmill electricity, and composting and sustainable agriculture did survive, but without their previous ideological context which gave them political meaning (Pursell, 1993). The reasons for the decline of the movement are considered complex and political (see Pursell, 1993), and by the early 1980s, several concerns and internal disagreements emerged regarding appropriate technologies. Some interpretations suggest that the appropriate technology movement merged into the 
sustainable development discourse in the 1980s (Oelschlaeger, 1995), and continues influencing discussions around technology and its role in development on that arena. However, it is not by any means the dominant way of articulating sustainable innovation for the poor anymore, as the growing influence of the sustainable development agenda throughout the 1990s led to a much more aggressive, business-driven articulation of sustainable innovation for the poor.

\section{Tracing Back Market-Based Innovations for the Poor: Base of the Pyramid}

The business-driven discourse developed as a corporate response to the overarching call for sustainable development launched at the Earth Summit in 1992. Business actors, represented by the World Business Council for Sustainable Development (WBCSD) first mobilized a set of solutions to the sustainable development question through the Corporate Social Responsibility (CSR) discourse. The CSR approach paved the way for corporations gaining a more legitimate space in social and environmental questions pertaining to sustainable development. Thus, it did not come as a surprise, when after a decade of CSR-led poverty reduction activities struggling to showcase satisfactory performance (Arora \& Romijn, 2012), a controversial solution was revived on the international arena of sustainable development: making a profit while reducing poverty in developing countries (Prahalad \& Hart, 2002). Towards the end of the millennium, market-based strategies for poverty alleviation were no longer considered as alternative or philanthropic and instead started to become dominant in discourses on global poverty (Chatterjee, 2014). A stream of literature and practice regarding the 'Base of the Pyramid' $(\mathrm{BoP})$ then built upon this business-friendly idea (e.g., Calton et al., 2013; Dembek et al., 2019; Lashitew et al., 2020). Borrowing from economics, the BoP population refers to the poorest but largest socio-economic grouping of the world. This group consists of 3 billion people who lived on less than around $\$ 2.50$ per day in 2002, as defined and popularized by Prahalad and Hart (2002). In the original discourse, the BoP was seen as a potentially vast market that had not been successfully "tapped" through the sales of products, services and technological innovations. Thus, the BoP population was naturalized as a market with specific characteristics in a system of differentiations as a basis for market segmentation and strategy. Adding to the profit arguments, other motives for businesses to engage with BoP markets would encompass the already attractive CSR agendas, or market entry justifications. The prominent theme in BoP thinking emphasized the opportunities for companies to make money from selling to people with low incomes, while at the same time improving their quality of life through material solutions. The underlying rhetoric thus touched upon the poverty-reducing benefits of companies operating in the BoP market. Such an inviting discourse was quickly adopted by business interest groups such as WBCSD. Significant tensions emerged, however, when simultaneously trying to pursue the goals of the BoP ideology in practice; consequently, in the academic discussions, the BoP discourse has contributed to decades' worth of heavily criticized results with the role of private business in reducing poverty (see e.g. Faria \& Hemais, 2017; Banerjee, 2007; Prieto-Carrón et al., 2006).

Since its beginning, the BoP approach was very much focused on developing innovative new products and services for the poor, based on a seemingly clear logic of difference whereby transnational corporations make profits and the poor mainly consume their products. However, the idea of coming across other innovations while selling products to the poor developed simultaneously: in the early days of BoP, Hart and Christensen (2002) as well as Prahalad and Hart (2002) described rural markets as hotbeds of innovation that would act as sources of sustainable innovations. The poor should not only save money and consume products, but also become active in the sales and distribution of the products developed by corporations (Prahalad \& Hart, 2002). The ideal BoP subject then becomes a 'consumer-entrepreneur' (Prahalad, 2006, p. 60)—preferably an informal one-as per the intentions of the broader neoliberal political philosophy that shifts the focus from the state towards the individual (Chatterjee, 2014). This political philosophy, in its infancy in the original BoP discourse, later became central within the governance-driven discourse (analysed below) on cocreating frugal innovations with the poor, where individual grassroots entrepreneurs are celebrated as sustainability champions who not only distribute and sell products, but also develop innovative solutions to social problems.

\section{Sustainable Innovation by the Poor: Community-Driven Discourse on Grassroots Innovation}

The community-driven discourse is the second set of ideas that we identify as a historically influential discourse on frugal innovation. The community-driven discourse lends its vocabulary to innovations arising from the grassroots through bottom-up processes mobilized by communities and users (Gupta, 2013). Such innovations are ideally based on the needs of the 'communities' and tap into already existing resources, or traditional ways of coping with scarcity. Here, this discourse does not precede the actions of the poor communities and it is not necessarily framed as a response to the sustainable development challenge in the first place, but it packages already existing practices in a way that resonates with sustainable development discourse due to some of its characteristics (such as efficient use of scarce resources). Thus, while the community-driven discourse originates in 
particular, contextualized practices based on specific conditions of scarcity in differentiated places, as a discourse it does have an equivalential effect of lumping the many innovations into one emancipatory movement of grassroots innovations.

A general aim associated with the grassroots innovation discourse is the idea of obtaining control over the innovation process and actively participating in the planning of policies and regulations concerning technology and innovation (Letty et al., 2012). In grassroots innovations, the generation of innovation is attributed to civil society actors, instead of government or business (Tang et al., 2011), and the aims often support broader social changes (Hess, 2007). The value systems behind grassroots innovations are different than those associated with profit-driven, market-based innovations, and the discourse stimulates a debate about social and structural transformations in light of extant economic and political systems (Smith et al., 2014).

Many grassroots innovation movements are and have been politically radical, and hold out a vision to put an end to unequal knowledge regimes. Grassroots innovation discourse typically portrays innovations originating from common people who address very practical problems of everyday life, with limited material resources (Seyfang \& Haxeltine, 2012). Such an emphasis has brought recognition to the importance of people's indigenous innovation capabilities, and the coping strategies needed for solutions to immediate problems (Smith et al., 2014). In contrast to BoP literature, grassroots solutions supposedly empower local communities through meeting basic needs endogenously, and by the people themselves. However, the grassroots discourse does incorporate aspects that frame them as malleable for corporate interests. Similarly to frugal innovations, grassroots innovations are locally specific yet widely applicable (Smith et al., 2014). This idea of scalability potentially resonates with market interests looking for growth potential, and we will see that the hegemonic discourse made this question of 'scaling up' central.

\section{Grassroots Innovations and the Question of Poverty}

The legacy of grassroots innovations has a long and persistent history in India, and while there have been discussions of frugal innovation in other parts of the Global South, much of the discursive elaboration on frugal innovation originates in India. Mahatma Gandhi was a strong proponent of local solutions and innovations, and it is no surprise that grassroots innovations often continue carrying his name as 'Gandhian innovations' (Prahalad \& Mashelkar, 2010). With a history of several grassroots innovation movements (see e.g. People's Science Movements and the Honey Bee Network), the context of India provides a complex and interesting setting for discussing grassroots innovations. Today many scholars prescribe those grassroots innovations known as jugaad, a Hindi word designating rough-and-ready improvisations with limited resources to overcome seemingly overwhelming everyday problems (Gulati, 2010; Krishnan, 2010; Radjou et al., 2012), presented as unique to the Indian context (Bound \& Thornton, 2012; Nair et al., 2015). The US Department of Commerce has singled out India for its innovative capabilities stating that "there are many Indian firms that have learned to conduct $\mathrm{R} \& \mathrm{D}$ in highly resource-constrained environments and who have found ways to use locally appropriate technology..." (US Department of Commerce, 2012). Radjou et al. (2012) further posited that "the West" should learn from places like India, China, and the African continent for a novel, bottom-up approach to sustainable innovation. In their argument, the time for corporations to follow the old formula that spurred innovation and economic growth for decades has come to an end. The old mix of top-down planning, and rigid, expensive, heavily structured innovation processes is not successful anymore.

Grassroots innovation movements have been influential in drawing global attention to the so-called 'below-theradar innovations' in the Global South (Pansera, 2013), and paving the way for alternative narratives on innovations to occupy legitimate spaces. The power of the grassroots innovation discourse within the Indian context not only gains its strength from the neoliberal celebration of the entrepreneurially spirited creative individual, but also from the type of innovation that gets promoted within the discourse. Since its independence, a long-standing distrust towards foreign technologies, protection from international competition and strict regulations for technology transfer had an influence in isolating India from external innovations (Nair et al., 2015). Furthermore, many anti-imperialist voices, such as Mahatma Gandhi's, blamed the British technology for ruining the Indian economy, and wanted to promote simple, small-scale technologies and local development instead (Nair et al., 2015). In recent years, the Hindu nationalist Bharatiya Janata Party has also invoked similar sentiments by highlighting the superiority of indigenous Indian innovations. Grassroots innovations resonate well with such discourses, and simultaneously emphasize the uniqueness and diversity of Indian creative innovations. While there are equivalential aspects to this type of Global South populism framed against innovations coming from the Global North, there is also much exclusion and affirmation of difference in such nationalist political strategy, preventing frugal innovation from being a real counter-hegemonic project beyond domestic borders.

\section{Changing Perceptions on Grassroots Innovations-Towards a Governance-Driven Approach}

The mandate for scaling up grassroots innovations has been strongly supported by the governmental bodies in India. As 
innovation policies have started to attend to issues of poverty, the idea of social inclusion advocated by grassroots innovation movements has gained attention for producing contextual knowledge required for constructing sustainable futures (Smith et al., 2014). In India, inclusive growth has been set as a priority in the national Science, Technology and Innovation Policy since 2003 (STI Policy, 2003). Unlike much innovation research and development elsewhere, in the Indian context, there appears to be substantial focus on innovation that serves the need of the poor (Nair et al., 2015). The Indian government has taken a strategic supportive role in scaling up grassroots innovations. Established in 2000, the National Innovation Fund's (NIF) mission is to "help India become inventive and creative, and to become a global leader in sustainable technologies without social and economic handicaps affecting the evolution and diffusion of green grassroots innovations" (NIF, 2019). At the first biennial innovation competition organized by NIF in 2000, more than 1600 applications were submitted; in 2015 the submission rate reached 33500 (NIF, 2016). The popularity of the initiative reflects the lucrativeness of the discourse on the creative grassroots inventor; it also taps into the desires of not wanting to be a rural peasant in a country with severe structural inequalities.

The recent shifts in India's innovation policies have gradually started to manifest themselves in the changing attitudes and discourses towards grassroots innovation. As an illustrative example, the concept of jugaad has experienced an interesting transformation during the recent decade. With its origins in the Indian countryside (Brem \& Wolfram, 2014), jugaad used to be typically constructed as a rather negative phenomenon in the Indian context (Radjou et al., 2012; Sekhsaria, 2013). Adding to its semantic meanings associated with improvisation, jugaad can also refer to a "trick" or "cunning device" (Monier-Williams, 1899). The term has a historical baggage of referring to an informal, clumsy, stopgap solution to a complex problem, which might not always conform with legal criteria (Birtchnell, 2011; Krishnan, 2010). Such a negative connotation may originate from the political context, since the governmental order in India has typically wanted to frame the messy informal sector with a degree of intolerance (Chatterjee, 2008). Recently, however, the discourse has changed towards something more positive. There has been an intentional attempt to transform the concept of jugaad into a distinguished form of improvised solution born out of smartness. This shift has been amplified by Radjou et al.'s (2012) influential book Jugaad Innovation: Think frugal, be flexible, Generate Breakthrough Growthwhich is also the most cited publication on frugal innovation. In their book, the authors narrate untold stories of creative jugaad entrepreneurs and innovations to show how global corporations can endorse jugaad to succeed in a resource constrained world. Another form of the attempt in polishing the image of jugaad innovations has been the establishment of 'The Better India' media platform that shares positive and uplifting stories of "unsung heroes, changemakers, innovations" (The Better India, 2019) through newsletters and social media outlets. Financed by private investors, these stories are currently reaching tens of millions of people every month with a clear message of celebrating jugaad and grassroots innovations. The recent changes within the use of grassroots innovation discourse in India serve as an observation to support our argument on the hegemonic formation of the governance-driven discourse on co-creating frugal innovations, to which we now turn.

\section{Sustainable Innovation with the Poor: Governance-Driven Discourse on Co-creating Frugal Innovations}

The governance-driven discourse on sustainable innovation has been directly inspired by the attempts of defining sustainable development as a governance challenge at various scales. This discourse has recently incorporated a local dimension into its sets of meanings and practices (Kumpf, 2017). The governance-driven discourse is often centered around a neutralized partnership imperative between business and other actors (e.g., Glasbergen, 2011). When transferring such imperatives to the local level, partnerships have come to manifest themselves within the new approach of co-creating sustainable innovations with 'the poor'. The governance-driven discourse has become hegemonic through its injunction to 'co-create' frugal innovation, where the particular meanings of the BoP, Appropriate Technology discourse and the grassroots innovation discourse are crafted into a win-win-win totality that allows for all groups to share partial, superficial beliefs.

\section{Co-creating Innovations with the Poor}

As a concept originating in marketing and strategy, (value) co-creation has been defined as the active involvement of end-users in various phases of the product development process (Prahalad \& Ramaswamy, 2000; Vargo \& Lusch, 2004). Co-creation puts more emphasis on the active involvement of end-users than, for example, participation, which might also indicate passive involvement (Voorberg et al., 2015). Within critical marketing and critical management studies, the co-optive power of co-creation has been problematized in various ways. It has been noted that (1) co-creation leads to a problematic blurring of boundaries between production and consumption (Fontenelle, 2015; Zwick et al., 2008), (2) the logic of co-creation makes consumers contribute to producer innovation while preserving or enhancing producer power (Bauer \& Gegenhuber, 2015; Zwick et al., 2008), (3) value co-creation literature tends to exaggerate the mutually 
beneficial nature of these processes, suppressing possible tensions (Cova et al., 2015b; Laamanen \& Skålén, 2015), and (4) those consumer contributions to for-profit innovations are typically unpaid and thus entail some degree of exploitation (Cova et al., 2015a; Gabriel et al., 2015; Zwick et al., 2008). While the above cited authors have all taken issue with problematic effects of co-creation on the weaker party (variously framed as consumer, customer, user or beneficiary), none of them have explicitly taken a meta-discursive perspective, looking into how co-creation as a signifier may enable discursive interventions that help in achieving or reproducing hegemonic logics. Drawing on Laclau and Mouffe's discourse theoretical approach, our argument here will be that in the context of sustainable innovation and more specifically in contemporary articulations of frugal innovation, co-creation acts as a powerful empty signifier. This empty signifier contributes to the hegemonic project of coopting the innovative power of populations in the Global South, by enabling the notion of frugal innovation with the poor.

This marks an important turning point, indeed what we might call a hegemonic intervention. First, what happens through the possibility to co-create frugal innovations with the poor signals a decisive grammatical change. This shift is anything but trivial since from a discourse theoretical perspective, grammar can be seen as articulatory of the politics of frugal innovation. Namely, the word 'with' is differential in itself, as it connects differential elements 'with' each other, making the chain of difference possible. Second, once the key missing element of co-creation becomes nodal in the governance-driven discourse, the other discourses on frugal innovations become perceived as 'lacking' the most important element. This is a characteristic of empty signifiers as the very condition of hegemony: they become present as that which is otherwise absent (Laclau, 1996).

In the context of sustainable innovation, co-creation has indeed become a panacea for innovating for sustainability. In the later versions of the BoP approach, which were developed in order to relegitimize the $\mathrm{BoP}$ proposition by making BoP less consumption-centred, the co-creative aspects of jointly developing products and services became popular (Arora \& Romijn, 2009). Most of the profitable BoP ventures, namely, were not managed by Western corporations as intended by the original BoP approach. Success stories include e.g. the Indian Jaipur Foot project and the Aravind Eye Care Project (Karnani, 2007), both of which contributed to the increasing interest towards Southern-led creative entrepreneurial initiatives. The observation that global corporations may not have particular advantages in competing in the BoP markets (Kolk et al., 2014) promotes the importance of facilitating partnerships and co-creation with local stakeholders, and fostering local entrepreneurship (Arora \& Romijn, 2009). One interesting detail indicating this shift was the change from the wording of "Bottom of the Pyramid" to "Base of the Pyramid" (Arora \& Romijn, 2009). This intentional change implies a broader message: "...the letter "B" in the abbreviation was re-baptized to "Base", to convey the positive idea of a platform or launchpad from which one can build upwards" (Arora \& Romijn, 2009, p. 485). This is indicative of a shift from a top-down mentality of the global, business-driven discourse towards a discourse that also accommodates a bottom-up, local communitydriven discourse.

Simanis and Hart (2009) propose that the fact that corporations failed at the BoP markets was illustrative of the necessary shift not only within the BoP approach, but also a sign of changing paradigms of corporate innovation strategy. Simanis and Hart (2009) categorize the so called previous 'BoP 1' model as the manifestation of the centuries-old 'Structural Innovation Paradigm' (SIP), where companies focus on solving the problems of customers in faster and cheaper ways than their competitors. The problem with this model, as Simanis and Hart (2009) argue, is that companies' innovation strategies and corporate growth remain disembedded from the society. Framing communities as target markets and only focusing on transactional engagement does not lead to long-term success at the BoP markets (2009, p. 13). Instead, they suggest that a new paradigm should be adopted, the so called 'Embedded Innovation Paradigm' (EIP). The EIP is based on incorporating broader societal values and the local environment into the business, thus 'embedding' the corporation into the local context. The focus is not on reaching increased material consumption for the consumers, but on stakeholder transformation that "creates new habits and identities necessary for realizing a new enterprise and strategic community intent" (2009, p. 15). Through the processes of local engagement and 'becoming embedded', companies and communities can jointly build new, shared identities. Transforming potential consumers into stakeholders that share closeness and mutual commitment with the company constitutes 'business intimacy' (Simanis \& Hart, 2009, p. 14), a competitive source of value.

\section{Co-creation and Associated Key Signifiers}

The discourse on sustainable innovation with the poor leverages co-creation-while using frugal innovation as a more ambiguous signifier than in the other two discourses- to make it possible to draw extensively on both BoP discourse and key terms associated with grassroots innovations (such as jugaad in India, now used routinely by businesses). In this discourse where the central objective of grassroots innovations is systematically argued to be to 'scale up' (another key signifier), grassroots networks become thoroughly co-opted. Business and scaled up grassroots innovations (preferably 'co-created', 
combining grassroots labour and business benefit) thus become the ostensible best means to tackle the SDGs.

In this discourse, 'co-creation' is a radically open signifier which might encompass anything from the most benevolent cooperation to the most extreme exploitation (where the labour of one of the 'co-creators' may often be tapped in by the business co-creator for no pay at all), at the same time as it makes an implicit and often explicit link to 'value creation' (cf. Porter \& Kramer, 2006). In Laclau and Mouffe's (1985) terms, what this empty signifier does is establishing and sustaining a chain of difference, because while all people are claimed to benefit from frugal innovations with the poor, both the roles and ways of benefiting from frugal innovation remain fully differentiated. On the one hand, transnational corporations make a killing thanks to the scaling up of frugal innovations, and the Global South elites find a solution to their 'inclusive development' problem while getting more lucrative opportunities too. On the other, while some of 'the poor' are rhetorically 'empowered' and become (often exploited) 'entrepreneurs', most of the people living in poverty remain 'beneficiaries' from frugal innovation largely in a passive subject position. The 'co-' in 'co-creation' implies that parties with different identities and a belief in a common interest work together-this is why the persistence of extreme inequalities and exploitation is tolerated, and here lies the co-optive power of co-creation.

Besides BoP and 'scaling up', other key signifiers relied upon in this discourse include 'embeddedness' (Simanis \& Hart, 2009) and of course the omnipresent 'partnership' which often serves as a discursive lever for business to co-opt communities and NGOs (see Burchell \& Cook, 2013; Laasonen et al., 2012). Thus, our interpretation is that the governancedriven discourse relying on sustainable development and SDGs has been successful as a hegemonic project, notably thanks to its central notion of co-creation with the poor. This discourse breaks with the particularisms of community grassroots innovations on the one hand and business innovations for the poor (and for profit) on the other, and hegemonizes sustainable innovation by presenting both the business-driven and community-driven articulations of frugal innovation as part of one broader, all-encompassing solution to sustainability challenges. And by doing this, the discourse also crushes any possibility of a counter-hegemonic chain of equivalence for a more grassroots-based frugal innovation discourse, instead sustaining a chain of difference in which the respective roles and benefits of all involved are differentiated.

\section{Discussion and Conclusions}

In this paper we have analysed how the recently popularized concept of frugal innovation has gained meaning through the business-driven, community-driven and governance-driven discourses on sustainable innovation. By analyzing these discourses as developing innovations for the poor, by the poor and with the poor we were able to trace a hegemonic re-arrangement involving different visions of frugal innovations. By accommodating interests from both the businessand community-driven discourses on sustainable innovation, the governance-driven discourse on co-creating frugal innovations with the poor is becoming hegemonic, and it seemingly is being successful in securing new benefits for the elites while promoting neoliberal entrepreneurialism for the poor. Our contribution lies in exposing the particular role of 'co-creation' as a powerful empty signifier originating from business studies. This signifier acquired co-optive power within the field of marketing (Zwick et al., 2008) and later was successfully imported into the discussion on frugal innovation, particularly via the BoP approach (also originating from strategic marketing) and as a way to bridge that approach with one framed as more win-win and more governance-oriented. What we believe is particularly novel in our analysis, at least within the fields of business and society and critical management studies, is how we unpack the role of particular signifiers in establishing and sustaining a chain of difference-in previous studies the role of empty signifiers in relation to chains of equivalence has been foregrounded, but not that in relation to chains of difference, even in those articles that discuss examples of chains of difference (Contu et al., 2013; Nyberg et al., 2018). 'Co-creation' works for the chain of difference because it is connective as any empty signifier should be, but it does not create equivalence. Instead it merely connects very different parties involved in frugal innovation from top-down and bottom-up perspectives, and plays the role of a tertium quid, an indefinite signifier that connects a number of definite signifiers, while distinct from all of them. In forming the chain, it is assisted not so much by definite 'moments' but instead by a number of other signifiers that are used in an ambiguous manner for the purpose of claiming benefits for all while keeping them differentiated, such as BoP, embeddedness, inclusion, partnership and scaling up.

It is not the first time that ideas associated with marketing and business ethics are shown to become powerful signifiers in the context of national and transnational governance-for example business-NGO partnerships (Laasonen et al., 2012), CSR (Zueva \& Fairbrass, 2019) and multi-stakeholder initiatives (Fougère \& Solitander, 2020) all have been discussed as signifiers from business studies with an impact on broader societal governance. Neither is it the first time that co-optive dimensions of empty signifiers have been discussed in business studies-a previous example being workplace mindfulness (Islam et al., 2017). But in contrast with previous studies, our focus is also on the dynamic discursive interactions between several signifiers in a particular hegemonic intervention. Through this intervention, a floating signifier 
with radical potential, frugal innovation, has been hijacked and co-opted in a hegemonic project that has leveraged several other powerful ambiguous signifiers such as co-creation, BoP, partnerships, which are associated with marketing and business ethics. We believe that rather than contributing to business theories that have problematic power effects, exposing those effects is a particularly worthy endeavour that is a contribution in its own right.

Thus, our analysis urges us to be vigilant to a number of critical implications of the advent of the hegemonic co-creation discourse on frugal innovation. First, the inherent positivity of frugal innovations framed as win-wins (Meagher, 2018) combined with their corporate-friendly articulation may become yet another lever-besides philanthropy, CSR, business-NGO or multi-stakeholder partnerships, etc.--for corporations to reclaim legitimacy by delivering 'development' in environments where their social license to operate has been challenged (Böhm \& Brei, 2008; Moog et al., 2015). For example, in the context of India, a company like Coca Cola, often strongly criticized for its negative impacts on local communities living near its production facilities, has been very happy to share its distribution channels with a social business called 'ColaLife' in order to distribute a package of frugal innovations that help fighting child mortality in remote communities (see Nari Kahle et al., 2013). This possibility of reclaiming corporate legitimacy through support for scaling up frugal innovations is often supported by national STI policies enforcing broader discursive legitimations for inclusive innovations for and with the poor, as in the case of India.

Second, following insights from critical marketing and critical management studies (Cova et al., 2011, 2015a; Gabriel et al., 2015; Zwick et al., 2008), one cannot but think of the possibilities of exploitation that come with 'co-creation'. Specifically in this context, what is likely to happen based on the new hegemonic understanding of frugal innovation is a heightened extraction, exploitation and scaling up of 'creative sustainability value' from individuals or communities. The grassroots co-innovators tend not to readily have access to ways to protect their frugal innovations (such as patents or other forms of legal protection), notably because they typically work in the 'informal sector' - while formal economic actors increasingly reap the benefits of frugal innovation (for a detailed description of how this happens, see Meagher, 2018).

Third, relatedly but going beyond mere exploitation of creativity, the hegemonization of sustainable innovation along the lines of co-creation can be seen as inscribed in a broader biopolitical project of governing the poor through including them more strongly in the market realm as entrepreneurs (see Varman et al., 2012) or, as BoP proponents would say, 'consumer-entrepreneurs' (Prahalad, 2006), thanks to the increasingly usual discursive mix of 'empowerment' and 'responsibilization' (see e.g., Ilcan \& Lacey, 2011). In this project, co-creation is a key signifier for articulating an illusory win-win (Meagher, 2018). Here, the resulting further activation of frugal creativity, as enabled by 'co-creation', both heightens the possibilities of exploitation discussed above and is meant to serve as an engine for economic growth.

Fourth, and again relatedly, this reliance on entrepreneurs and markets to provide the solutions for challenges related to poverty also means that the state is assumed to be redundant in addressing these challenges. This is particularly harmful since the state uses its championing of co-creation frugal initiatives to justify reductions in welfare interventions-all while inequalities are heightened by the new entrepreneurial logic (Varman et al., 2012). As Meagher (2018) concludes, countering the disempowering effects of frugal co-creation for informal actors instead should entail much greater mobilization of the state. Similarly to social innovation in the EU (Fougère et al., 2017), frugal innovation in developing countries tends to be used in policy as a way to legitimize a less redistributive state.

That said, the openness of the hegemonic discourse means that it remains contested, and thus the emancipatory-and subversive-potential of frugal innovation should not be assumed to be completely lost. The idea of frugal innovation has arguably contributed to a more diverse understanding of the process of innovation. With close connections to the literature on grassroots innovations, it has created appreciation for the local embeddedness of innovations, and the value of solutions developed by people residing where the problems themselves are located (Gupta et al., 2003; Smith et al., 2014). It furthermore has challenged the notion of innovations as primarily outcomes of resource-intensive processes and the exclusive domain of economies in the global North with budgets to fund large investments in the development of technology (Kaplinsky, 2011). As frugal innovations have been celebrated, the dominant view seeing economies in the global South as mere recipients of technology has partially shifted, and the possibility for 'Southern' innovations to be inspirational for the counterparts in global North has been acknowledged (Bound \& Thornton, 2012; Fougère \& Harding, 2012). And one learning that people embedded in different localities around the world could get from the original grassroots articulations of frugal innovation could relate to the need of using those highly context-dependent resources that are locally at hand, in a frugal manner, rather than relying for everything on the global marketplace, which is the main reason for how overwhelmingly unsustainable our world has become. Most importantly, the fact that the discourse remains contested also means that by drawing on its original grassroots articulations, it remains possible to imagine a translocal 
counter-hegemonic movement calling for much more of the benefits of frugal innovation to be allocated by and to the poor, on their own terms.

Funding Open access funding provided by Hanken School of Economics.

\section{Declarations}

Conflict of interest The authors declare that they have no conflict of interest.

Research Involving Human Participants and/or Animals This study did not involve human participants (other than the authors) nor animals.

Informed Consent Since this study did not involve human participants other than the authors, it required no one's formal informed consent.

Open Access This article is licensed under a Creative Commons Attribution 4.0 International License, which permits use, sharing, adaptation, distribution and reproduction in any medium or format, as long as you give appropriate credit to the original author(s) and the source, provide a link to the Creative Commons licence, and indicate if changes were made. The images or other third party material in this article are included in the article's Creative Commons licence, unless indicated otherwise in a credit line to the material. If material is not included in the article's Creative Commons licence and your intended use is not permitted by statutory regulation or exceeds the permitted use, you will need to obtain permission directly from the copyright holder. To view a copy of this licence, visit http://creativecommons.org/licenses/by/4.0/.

\section{References}

Akubue, A. (2000). Appropriate technology for socioeconomic development in third world countries. The Journal of Technology Studies. https://doi.org/10.21061/jots.v26i1.a.6

Alvesson, M., \& Sandberg, J. (2020). The problematizing review: A counterpoint to Elsbach and Van Knippenberg's argument for integrative reviews. Journal of Management Studies, 57, 1290-1304.

Arora, S., \& Romijn, H. (2009). Innovation for the base of the pyramid: Critical perspectives from development studies on heterogeneity and Participation. UNU-MERIT working papers.

Arora, S., \& Romijn, H. (2012). The empty rhetoric of poverty reduction at the base of the pyramid. Organization, 19(4), 481-505.

Banerjee, S. B. (2007). Corporate social responsibility: The good, the bad and the ugly. Edward Elgar.

Bauer, R. M., \& Gegenhuber, T. (2015). Crowdsourcing: Global search and the twisted roles of consumers and producers. Organization, 22(5), 661-681.

Bell, M., \& Franceys, R. (1995). Improving human welfare through appropriate technology: Government responsibility, citizen duty or customer choice. Social Science and Medicine, 40(9), 11691179. https://doi.org/10.1016/0277-9536(94)00238-O

Bell, E., \& Willmott, H. (2020). Ethics, politics and embodied imagination in crafting scientific knowledge. Human Relations, 73(10), 1366-1387.
Bhatti, Y. A. (2012). What is frugal, what is innovation? Towards a theory of frugal innovation. Retrieved July 22021 from https:// papers.ssrn.com/sol3/papers.cfm?abstract_id=2005910.

Bhatti, Y. A., \& Ventresca, M. (2012). The emerging market for frugal innovation: fad, fashion, or fit? SSRN Electronic Journal. https:// doi.org/10.2139/ssrn.2005983

Birtchnell, T. (2011). Jugaad as systemic risk and disruptive innovation in India. Contemporary South Asia, 19(4), 357-372.

Böhm, S., \& Brei, V. (2008). Marketing the hegemony of development: Of pulp fictions and green deserts. Marketing Theory, 8(4), 339-366.

Bound, K., \& Thornton, I. W. (2012). Our frugal future: Lessons from India's innovation system. Nesta London. Retrieved from https:// www.nesta.org.uk/report/our-frugal-future-lessons-from-indiasinnovation-system/.

Brem, A., \& Wolfram, P. (2014). Research and development from the bottom up-introduction of terminologies for new product development in emerging markets. Journal of Innovation and Entrepreneurship, 3(1), 9.

Brown, T. (2016). Sustainability as empty signifier: Its rise, fall, and radical potential. Antipode, 48(1), 115-133.

Burawoy, M. (1979). Manufacturing consent: Changes in the labor process under monopoly capitalism. University of Chicago Press.

Burchell, J., \& Cook, J. (2013). CSR, co-optation and resistance: The emergence of new agonistic relations between business and civil society. Journal of Business Ethics, 115(4), 741-754.

Calton, J. M., Werhane, P. H., Hartman, L. P., \& Bevan, D. (2013). Building partnerships to create social and economic value at the base of the global development pyramid. Journal of Business Ethics, 117(4), 721-733.

Chatterjee, P. (2008). Democracy and economic transformation in India. Economic and Political Weekly. https://doi.org/10.21648/ arthavij/2008/v50/i1/115446

Chatterjee, S. (2014). Engaging with an emergent metanarrative: A critical exploration of the BoP proposition. Organization, 21(6), $888-906$.

Collins. (2021). Definition of tertium quid. Retrieved July 22021 from https://www.collinsdictionary.com/dictionary/english/terti um-quid.

Contu, A., Palpacuer, F., \& Balas, N. (2013). Multinational corporations' politics and resistance to plant shutdowns: A comparative case study in the south of France. Human Relations, 66(3), 363-384.

Cova, B., Dalli, D., \& Zwick, D. (2011). Critical perspectives on consumers' role as 'producers': Broadening the debate on value co-creation in marketing processes. Marketing Theory, 11(3), 231-241.

Cova, B., Pace, S., \& Skålén, P. (2015a). Brand volunteering: Value co-creation with unpaid consumers. Marketing Theory, 15(4), 465-485.

Cova, B., Pace, S., \& Skålén, P. (2015b). Marketing with working consumers: The case of a carmaker and its brand community. Organization, 22(5), 682-701.

de Cleen, B., Glynos, J., \& Mondon, A. (2018). Critical research on populism: Nine rules of engagement. Organization, 25(5), 649-661.

Dembek, K., Sivasubramaniam, N., \& Chmielewski, D. A. (2019). A systematic review of the bottom/base of the pyramid literature: Cumulative evidence and future directions. Journal of Business Ethics. https://doi.org/10.1007/s10551-019-04105-y

Edward, P., \& Willmott, H. (2008). Structures, identities and politics: Bringing corporate citizenship into the corporation. In A. G. Scherer \& G. Palazzo (Eds.), Handbook of research on global corporate citizenship (pp. 405-429). Edward Elgar. 
Faria, A., \& Hemais, M. (2017). Rethinking the bottom of the pyramid: A critical perspective from an emerging economy. Marketing Theory, 17(3), 271-287.

Fontenelle, I. A. (2015). Organisations as producers of consumers. Organization, 22(5), 644-660.

Foucault, M. (2002). Archaeology of knowledge. Routledge.

Fougère, M., \& Harding, N. (2012). On the limits of what can be said about 'innovation': Interplay and contrasts between academic and policy discourses. In K.-E. Sveiby, P. Gripenberg, \& B. Segercrantz (Eds.), Challenging the innovation paradigm. Routledge.

Fougère, M., \& Solitander, N. (2020). Dissent in consensusland: An agonistic problematization of multi-stakeholder governance. Journal of Business Ethics, 164, 683-699.

Fougère, M., Segercrantz, B., \& Seeck, H. (2017). A critical reading of the European Union's social innovation policy discourse: (Re) legitimizing neoliberalism. Organization, 24(6), 819-843.

Fournier, V., \& Grey, C. (2000). At the critical moment: Conditions and prospects for critical management studies. Human Relations, 53(1), 7-32.

Gabriel, Y., Korczynski, M., \& Rieder, K. (2015). Organizations and their consumers: Bridging work and consumption. Organization, 22(5), 629-643.

Glasbergen, P. (2011). Understanding partnerships for sustainable development analytically. The ladder of partnership activity as a methodological tool. Environmental Policy and Governance, 21(1), 1-13

Godin, B. (2016). Technological innovation: On the origins and development of an inclusive concept. Technology and Culture, 57(3), 527-556.

Gripenberg, P., Sveiby, K.-E., \& Segercrantz, B. (2012). Challenging the innovation paradigm: The prevailing pro-innovation bias. In K.-E. Sveiby, P. Gripenberg, \& B. Segercrantz (Eds.), Challenging the innovation paradigm. Routledge.

Gulati, R. (2010). Management lessons from the edge. Academy of Management Perspectives, 24(2), 25-28.

Gupta, A. K. (2006). From sink to source: The honey bee network documents indigenous knowledge and innovations in India. Innovations: Technology, Governance, Globalization, 1(3), 49-66.

Gupta, A. K. (2013). Tapping the entrepreneurial potential of grassroots innovation. Stanford Social Innovation Review, 11(3), $18-20$.

Gupta, A. K., Sinha, R., Koradia, D., Patel, R., Parmar, M., Rohit, P., Patel, H., Patel, K., Chand, V. S., James, T. J., Chandan, A., Patel, M., Prakash, T. N., \& Vivekanandan, P. (2003). Mobilizing grassroots' technological innovations and traditional knowledge, values and institutions: Articulating social and ethical capital. Futures, 35(9), 975-987.

Hart, S. L., \& Christensen, C. M. (2002). The great leap: Driving innovation from the base of the pyramid. MIT Sloan Management Review, 44(1), 51-56.

Hazeltine, B., \& Bull, C. (1999). Appropriate technology: Tools, choices and implications. Academic Press.

Hess, D. J. (2007). Alternative pathways in science and industry: Activism, innovation and the environment in an era of globalization. MIT Press.

Hossain, M. (2016). Grassroots innovation: A systematic review of two decades of research. Journal of Cleaner Production, 137, 973-981.

Hossain, M. (2018). Frugal innovation: A review and research agenda. Journal of Cleaner Production, 182, 926-936.

Howarth, D. (2005). Applying discourse theory: The method of articulation. In D. Howarth \& J. Torfing (Eds.), Discourse theory in European politics. Palgrave Macmillan.

Howarth, D. (2006). Space, subjectivity, and politics. Alternatives, $31(2), 105-134$
Ilcan, S., \& Lacey, A. (2011). Governing the poor: Exercises of poverty reduction, practices of global aid. McGill-Queen's University Press.

Islam, G., Holm, M., \& Karjalainen, M. (2017). Sign of the times: Workplace mindfulness as an empty signifier. Organization. https://doi.org/10.1177/1350508417740643

Jørgensen, M. W., \& Phillips, L. J. (2002). Discourse analysis as theory and method. Sage.

Kaplinsky, R. (2011). Schumacher meets Schumpeter: Appropriate technology below the radar. Research Policy, 40, 193-203.

Kaplinsky, R., \& Farooki, M. (2010). What are the implications for global value chains when the market shifts from the north to the south? World Bank policy research working paper 5205, February 2010.

Karnani, A. (2007). The mirage of marketing to the bottom of the pyramid: How the private sector can help alleviate poverty. California Management Review, 49(4), 90-111.

Kelly, S. (2013). Towards a negative ontology of leadership. Human Relations, 67(8), 905-922.

Kenny, K., \& Bushnell, A. (2020). How to whistle-blow: Dissensus and demand. Journal of Business Ethics, 164, 643-656.

Kenny, K., \& Scriver, S. (2012). Dangerously empty? Hegemony and the construction of the Irish entrepreneur. Organization, 19(5), 615-633.

Knights, D., \& Morgan, G. (1991). Corporate strategy, organizations, and subjectivity: A critique. Organization Studies, 12(2), 251-273.

Knorringa, P., Peša, I., Leliveld, A., \& Van Beers, C. (2016). Frugal innovation and development: Aides or adversaries? European Journal of Development Research, 28, 143-153.

Kolk, A., Rivera-Santos, M., \& Rufín, C. (2014). Reviewing a decade of research on the "base/bottom of the pyramid" (BOP) concept. Business \& Society, 53(3), 338-377.

Krishnan, R. T. (2010). From Jugaad to systematic innovation: The challenge for India. Utpreraka Foundation.

Kumpf, B. (2017). Four trends in development innovation. UNDP. Retrieved July 22021 from https://web.archive.org/web/20180 725062526/http://www.undp.org/content/undp/en/home/blog/ 2017/7/12/Spark-Scale-Sustain/.

Laamanen, M., \& Skålén, P. (2015). Collective-conflictual value cocreation: A strategic action field approach. Marketing Theory, 15(3), 381-400.

Laasonen, S., Fougère, M., \& Kourula, A. (2012). Dominant articulations in academic business and society discourse on NGObusiness relations: A critical assessment. Journal of Business Ethics, 109(4), 521-545.

Laclau, E. (1996). Why do empty signifiers matter to politics. Emancipation(s). Verso.

Laclau, E. (2005). On populist reason. Verso.

Laclau, E., \& Mouffe, C. (1985). Hegemony and socialist strategy. Verso.

Lashitew, A. A., Bals, L., \& van Tulder, R. (2020). Inclusive business at the base of the pyramid: The role of embeddedness for enabling social innovations. Journal of Business Ethics, 162(2), 421-448.

Letty, B., Shezi, Z., \& Mudhara M. (2012). An exploration of agricultural grassroots innovation in South Africa and implications for innovation indicator development. UNU-MERIT working paper 23.

Liu, H., \& Pechenkina, E. (2019). Innovation-by-numbers: An autoethnography of innovation as violence. Culture and Organization, 25(3), 178-188.

Mäkinen, J., \& Kourula, A. (2012). Pluralism in political corporate social responsibility. Business Ethics Quarterly, 22(4), 649-678. 
Meagher, K. (2018). Cannibalizing the informal economy: Frugal innovation and economic inclusion in Africa. The European Journal of Development Research, 30(1), 17-33.

Merriam Webster. (2019). Definition of frugal. Merriam Webster online dictionary and thesaurus. Retrieved July 22021 from https://www.merriam-webster.com/dictionary/frugal.

Mills, C. W. (1959). The sociological imagination. Oxfors University Press.

Monier-Williams, M. (1899). Sanskrit-english dictionary. Bhartiya Granth NIketan.

Moog, S., Spicer, A., \& Böhm, S. (2015). The politics of multi-stakeholder governance initiatives: The case of the forest stewardship council. Journal of Business Ethics, 128(3), 469-493.

NariKahle, H., Dubiel, A., Ernst, H., \& Prabhu, J. (2013). The democratizing effects of frugal innovation: Implications for inclusive growth and state-building. Journal of Indian Business Research, 5(4), 220-234.

Nair, A., Guldiken, O., Fainshmidt, S., \& Pezeshkan, A. (2015). Innovation in India: A review of past research and future directions. Asia Pacific Journal of Management, 32(4), 925-958.

NCAT. (2011). The national center for appropriate technology. "The History of NCAT". Retrieved July 22021 from https://web. archive.org/web/20180908202318/http://www.ncat.org/history/ .

NIF. (2016). Festival of innovation 2016: Building bridges for inclusive innovations. National Innovation Foundation, India.

NIF. (2019). National Innovation Foundation-India. Autonomous body of the Department of Science and Technology, Government of India. Mission statement. Retrieved July 22021 from http://nif.org.in/mission.

Nyberg, D., \& Wright, C. (2012). Justifying business responses to climate change: Discursive strategies of similarity and difference. Environment and Planning A, 44(8), 1819-1835.

Nyberg, D., Wright, C., \& Kirk, J. (2018). Dash for gas: Climate change, hegemony and the scalar politics of fracking in the UK. British Journal of Management, 29(2), 235-251.

O'Doherty, D. (2015). Missing connexions: The politics of airport expansion in the United Kingdom. Organization, 22(3), 418-431.

Oelschlaeger, M. (1995). Ethical considerations of sustainable futures. In S. R. Ingman, X. Pei, \& K. R. Bartlett (Eds.), An aging population, an aging planet, and a sustainable future. Center for Texas Studies.

Pansera, M. (2013). Frugality, grassroots and inclusiveness: New challenges for mainstream innovation theories. African Journal of Science, Technology, Innovation and Development, 5(6), 469-478.

Pansera, M., \& Martinez, F. (2017). Innovation for development and poverty reduction: An integrative literature review. Journal of Management Development, 36(1), 2-13.

Pansera, M., \& Owen, R. (2017). Innovation for de-growth: A case study of counter-hegemonic practices from Kerala, India. Journal of Cleaner Production, 197, 1872-1883.

Pansera, M., \& Sarkar, S. (2016). Crafting sustainable development solutions: Frugal innovations of grassroots entrepreneurs. Sustainability, 8(1), 51.

Perren, L., \& Sapsed, J. (2013). Innovation as politics: The rise and reshaping of innovation in UK parliamentary discourse 19602005. Research Policy, 42(10), 1815-1828.

Porter, M. E., \& Kramer, M. R. (2006). Strategy and society: The link between competitive advantage and corporate social responsibility. Harvard Business Review, 84(12), 78-92.

Prahalad, C. K. (2006). The fortune at the bottom of the pyramid, eradicating poverty through profits. Wharton School Publishing.

Prahalad, C. K., \& Hart, S. L. (2002). The fortune at the bottom of the pyramid. Strategy and Business, 26, 2-14.
Prahalad, C. K., \& Mashelkar, R. A. (2010). Innovation's holy grail. Harvard Business Review, 88, 132-141.

Prahalad, C. K., \& Ramaswamy, V. (2000). Co-opting customer competence. Harvard Business Review, 78, 79-90.

Prieto-Carrón, M., Lund-Thomsen, P., Chan, A., Muro, A., \& Bhushan, C. (2006). Critical perspectives on CSR and development: What we know, what we don't know and what we need to know. International Affairs, 82(5), 977-987.

Pursell, C. (1993). The rise and fall of the appropriate technology movement in the United States, 1965-1985. Technology and Culture, 34(3), 629-637.

QuistgaardSteensen, K., \& Villadsen, K. (2020). From social gospel to CSR: Was corporate social responsibility ever radical? Organization, 27(6), 924-942.

Radjou, N., \& Prabhu, J. C. (2014). Frugal innovation: How to do more with less (1st ed.). Public Affairs.

Radjou, N., Prabhu, J., \& Ahuja, S. (2012). Jugaad innovation: Think frugal, be flexible, generate breakthrough growth. Wiley.

Schrempf, J. (2014). A social connection approach to corporate responsibility: The case of the fast-food industry and obesity. Business and Society, 53(2), 300-332.

Schumacher, E. F. (1973). Small is beautiful: Economics as if people mattered. Harper and Row.

Sekhsaria, P. (2013). The making of an indigenous STM: Technological Jugaad as a culture of innovation in India. In K. Konrad, H. Van Lente, C. Coenen, A. Dijkstra, \& C. Milburn (Eds.), Shaping emerging technologies: Governance, innovation, discourse (pp. 137-152). IOS Press.

Seyfang, G., \& Haxeltine, A. (2012). Growing grassroots innovations: Exploring the role of community-based initiatives in governing sustainable energy transitions. Environment \& Planning C, 30(3), 381-400.

Simanis, E., \& Hart, S. L. (2009). Innovation from the inside out. MIT Sloan Management Review, Summer, 2009, 77-86.

Smith, A., Fressoli, M., \& Thomas, H. (2014). Grassroots innovation movements: Challenges and contributions. Journal of Cleaner Production, 63, 114-124.

Smolović Jones, O., Smolović Jones, S., \& Grint, K. (2020). Understanding sovereign leadership as a response to terrorism: A postfoundational analysis. Organization, 27(4), 537-556.

Spicer, A., \& Böhm, S. (2007). Moving management: Theorizing struggles against the hegemony of management. Organization Studies, $28,1667-1698$.

Spicer, A., \& Sewell, G. (2010). From national service to global player: Transforming the organizational logic of a public broadcaster. Journal of Management Studies, 47(6), 913-943.

STI Policy. (2003). Science and technology policy, Government of India. Retrieved July 22021 from http://www.kctu.kar.nic.in/ pdf/s\%20and\%20t\%20policy/2003.pdf.

Tang, T., Karhu, K., \& Hamalainen, M. (2011). Community innovation in sustainable development: A cross case study. World Academy of Science, Engineering and Technology, 73(1), 396-403.

The Better India. (2019). Retrieved July 22021 from https://www.thebe tterindia.com/about/.

The Economist. (2014). Under the radar: Innovation evolves in Asia. A report from the economist intelligence unit. The Economist, 14.10.2014. Retrieved July 22021 from https://eiuperspectives. economist.com/technology-innovation/under-radar.

Tiwari, R., Kalogerakis, K., \& Herstatt, C. (2016). Frugal innovations in the mirror of scholarly discourse: Tracing theoretical basis and antecedents. In R\&D Management Conference, Cambridge, UK.

Torfing, J. (1999). New theories of discourse: Laclau, Mouffe and Zizek. Blackwell. 
UN Secretary-General. (2017). UN secretary-general antónio guterres on world intellectual property day, April 26, 2017. Retrieved July 22021 from https://www.youtube.com/watch?v=Zmltxzfb3ns.

UN Sustainable Development. (2015). Resolution by the UN general assembly: Transforming our world: the 2030 Agenda for Sustainable Development. Retrieved July 22021 from http://www. un.org/ga/search/view_doc.asp?symbol=A/RES/70/1\&Lang=E.

US Department of Commerce. (2012). U.S. commerce secretary John Bryson Visits Jaipur Foot. Retrieved July 22021 from https:// 2010-2014.commerce.gov/news/press-releases/2012/03/28/uscommerce-secretary-john-bryson-visits-jaipur-foot.html.

Vargo, S. L., \& Lusch, R. F. (2004). Evolving to a new dominant logic for marketing. Journal of Marketing, 68(1), 1-17.

Varman, R., Skålén, P., \& Belk, R. W. (2012). Conflicts at the bottom of the pyramid: Profitability, poverty alleviation, and neoliberal governmentality. Journal of Public Policy \& Marketing, 31(1), 19-35.

Voegtlin, C., \& Scherer, A. (2017). Responsible innovation and the innovation of responsibility: Governing sustainable development in a globalized world. Journal of Business Ethics, 143, 227-243.

Voorberg, W. H., Bekkers, V. J., \& Tummers, L. G. (2015). A systematic review of co-creation and co-production: Embarking on the social innovation journey. Public Management Review, 17(9), 1333-1357.
WCED. (1987). World commission on environment and development: Our common future. Oxford University Press.

Wierenga, M. (2015). Local frugal innovations: How do resourcescarce innovations emerge in India? Master's thesis. Aalto University School of Business.

Young, I. M. (2011). Responsibility for justice. Oxford University Press.

Zeschky, M. B., Winterhalter, S., \& Gassmann, O. (2014). From cost to frugal and reverse innovation: Mapping the field and implications for global competitiveness. Research-Technology Management, 57(4), 20-27.

Zueva, A., \& Fairbrass, J. (2019). Politicising government engagement with corporate social responsibility: "CSR" as an empty signifier. Journal of Business Ethics. https://doi.org/10.1007/ s10551-019-04330-5

Zwick, D., Bonsu, S. K., \& Darmody, A. (2008). Putting consumers to work: Co-creation and new marketing govern-mentality. Journal of Consumer Culture, 8(2), 163-196.

Publisher's Note Springer Nature remains neutral with regard to jurisdictional claims in published maps and institutional affiliations. 